\title{
Screening and management of hypertension in a General Practice Outpatient Department of a tertiary level teaching hospital in eastern region of Nepal
}

\author{
AK Yadav ${ }^{1}$, OD Lewis ${ }^{1}$, SK, Sharma ${ }^{2}$, IP Mahato ${ }^{1}$, R Bhandari ${ }^{1}$, SK Gupta ${ }^{1}$, R Giri ${ }^{1}$, \\ M Paudel $^{1}$, PP Gupta ${ }^{1}$ \\ Department of General Practice and Emergency Medicine ${ }^{1}$, Department of Internal Medicine ${ }^{2}$ \\ B.P. Koirala Institute of Health Sciences, Dharan, Nepal
}

\begin{abstract}
Background: Hypertension is a common disease affecting about $20 \%$ of the adult population, both in developed and developing world (WHO 2002). It is one of the serious public health problems. Timely detection, compliance with lifestyle modification and use of drugs are important for effective management of this condition. Objective: To find out the prevalence of systemic hypertension in the general outpatient department and to study the effect of drugs and lifestyle education on the blood pressure over time. Methods: This was an interventional series of cases involving diagnosis and management of patients with BP higher than 140/90 or with known hypertension. All the subjects included were given life style education to see the effect of change of life style on blood pressure over time. Results: A total of 258 subjects were screened and 145 (56\%) were diagnosed as hypertensive. Of the total, 75 (29\%) had a blood pressure level in pre- hypertensive range. Whereas, 42 (16.3\%) had hypertension of stage 1, and 28 $(11 \%)$ had hypertension of stage 2. Forty- nine patients came for first follow up, 40 patients for second and 10 patients for the third follow up. Blood pressure started to decrease with second follow up. Conclusion: This study demonstrated that the prevalence of hypertension is $56 \%$ in the general outpatient department. The lifestyle education can have positive impact on blood pressure control.
\end{abstract}

Key words: Hypertension, life style modification, prevalence.

\section{Introduction}

Hypertension is a common disease affecting about $20 \%$ of the adult population, both in

\footnotetext{
Address for correspondence

Dr. Ashok Kumar Yadav

Associate Professor

Department of GP and EM

B.P. Koirala Institute of Health Sciences, Dharan

Email: dr yadavashok@yahoo.com
}

developed and developing world (WHO 2002). ${ }^{1}$ It is one of the serious public health problems of the world. Many people are unaware that they are hypertensive. Others have been diagnosed but fail to comply with treatment. 
Lowering blood pressure reduces the chance of cerebrovascular accidents. ${ }^{1,2}$ Hypertension is also associated with co-morbidities such as diabetes, ischemic heart disease, hyperlipidaemia, and chronic kidney disease. ${ }^{2}$ These chronic diseases need to be managed together. This research project focused on hypertension, but also addressed the other co-morbidities.

Strategies for screening and better management of these chronic diseases are urgently needed in primary care situations of countries like Nepal that are undergoing demographic transition. In the future it can be expected that the problem will be even bigger as the population distribution includes more old people.

Similar studies were found from the developed world, but not from Nepal or India. This study was designed to find out the prevalence of systemic hypertension and to follow up a subset of the diagnosed cases to look at changes in blood pressure over time. It also studied the effect of lifestyle education on the blood pressure over time

The motivation for this study was, therefore, to explore whether screening for hypertension in the General outpatient department (GOPD) waiting room was a useful tool for case finding of hypertension and whether following a protocol such as JNC7 would result in a measurable drop in blood pressure in these people.

\section{Methods}

This was an interventional series of cases done in the GOPD of BP Koirala Institute of Health Sciences (BPKIHS). A total of 258 patients were included in the study. The screening was done during outpatient hours and a convenience sampling method was used. Everyone of age more than 15 years in the waiting area of the GOPD was eligible for the study. The researcher made himself available for one hour every day for the research. Information about the screening process and research was given to everyone and those who volunteered for the research were taken as sample.

This study involved screening, diagnosis and management of the patients with blood pressure higher than 140/90 mmHg or known hypertension as per the Seventh Report of the Joint National Committee on the prevention, detection, evaluation and treatment of high blood pressure (JNC7). The persons who were diagnosed to have hypertension, were then counselled in terms of life style modification, investigated and treated as per the JNC 7 guidelines ${ }^{12,14}$ (Table- 1). 
Table 1: Classification and management of blood pressure for adults *

\begin{tabular}{|c|c|c|c|c|c|}
\hline \multirow[b]{2}{*}{$\begin{array}{c}\text { BP } \\
\text { classification }\end{array}$} & \multirow[b]{2}{*}{$\begin{array}{l}\mathrm{SBP}^{\star} \\
\mathrm{mmHg}\end{array}$} & \multirow[b]{2}{*}{$\begin{array}{l}\mathrm{DBP}^{\star} \\
\mathrm{mmHg}\end{array}$} & \multirow[b]{2}{*}{$\begin{array}{c}\text { Lifestyle } \\
\text { modification }\end{array}$} & \multicolumn{2}{|c|}{ Initial drug therapy } \\
\hline & & & & $\begin{array}{l}\text { Without } \\
\text { compelling } \\
\text { indication }\end{array}$ & $\begin{array}{c}\text { With } \\
\text { compelling } \\
\text { indications } \\
\text { (see table 8) }\end{array}$ \\
\hline Normal & $<120$ & and $<80$ & Encourage & \multirow{2}{*}{$\begin{array}{l}\text { No } \\
\text { antihypertensive } \\
\text { drug indicated. }\end{array}$} & \multirow{2}{*}{$\begin{array}{c}\text { Drug(s) for } \\
\text { compelling } \\
\text { indications. } \neq\end{array}$} \\
\hline Prehypertension & $120-139$ & or $80-89$ & Yes & & \\
\hline $\begin{array}{c}\text { Stage } 1 \\
\text { Hypertension }\end{array}$ & $140-159$ & or 90-99 & Yes & $\begin{array}{l}\text { Thiazide-type diuretics } \\
\text { for most. May consider } \\
\text { ACEI, ARB, BB, CCB, } \\
\text { or combination. }\end{array}$ & $\begin{array}{l}\text { Drug(s) for the } \\
\text { compelling } \\
\text { indications. } \ddagger \\
\text { Other }\end{array}$ \\
\hline $\begin{array}{c}\text { Stage } 2 \\
\text { Hypertension }\end{array}$ & $\geq 160$ & or $\geq 100$ & Yes & $\begin{array}{l}\text { Two-drug combination } \\
\text { for most } † \text { (usually } \\
\text { thiazide-type diuretic } \\
\text { and ACEI or } \\
\text { ARB or CCB). }\end{array}$ & $\begin{array}{c}\text { antihypertensive } \\
\text { drugs (diuretics, } \\
\text { ACEI,ARB, } \\
\text { BB, CCB) } \\
\text { as needed. }\end{array}$ \\
\hline
\end{tabular}

DBP,diastolic blood pressure; SBP, systolic blood pressure.

Drug abbreviations: ACEI, angiotensin converting enzyme inhibitor; ARB, angiotensin receptor blocker; $\mathrm{BB}$, betablocker;CCB, calcium channel blocker.

* Treatment determined by highest BP category.

$\dagger$ Initial combined therapy should be used cautiously in those at risk for orthostatic hypotension.

‡ Treat patients with chronic kidney disease or diabetes to BP goal of $<130 / 80 \mathrm{mmHg}$.
${ }^{*} \mathrm{BP}$ recorded by mercury sphygmomanometer by ausculatory method, taken after rest of 5 minutes, at least 2 recordings.

A follow- up plan was then formulated for diagnosed hypertension cases. A total of three follow ups at 2 weeks, 4 weeks, and 3 months were planned. The patients living farther away could request to be referred to a local practitioner for follow-up and were considered lost to follow-up for the purpose of this study. The main outcome measure of the 
study was to see the effect of drugs and life style modification on blood pressure.
An informed consent was taken from all the subjects included in the study.

Total number of patients (258)

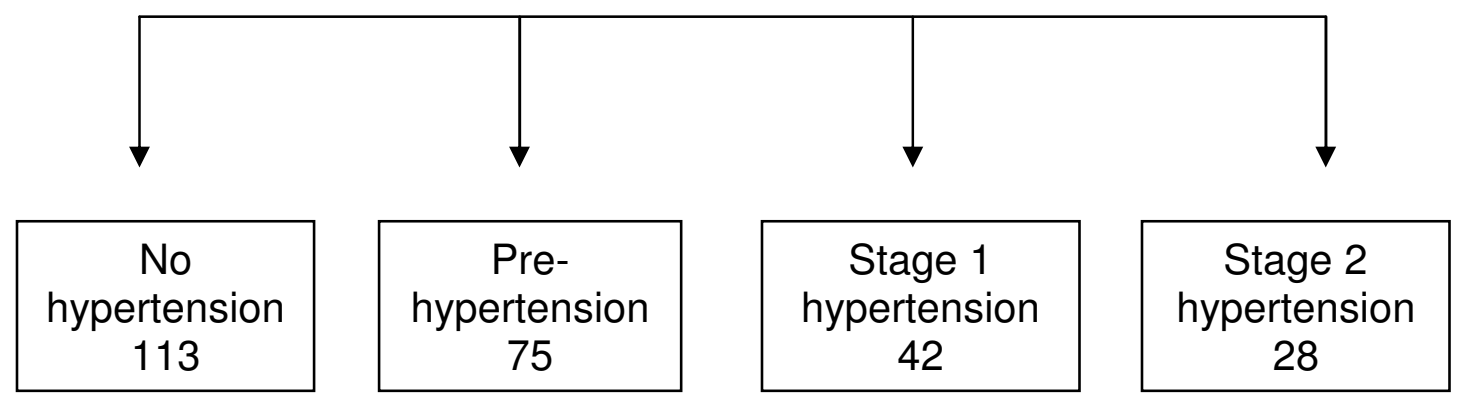

Follow-up

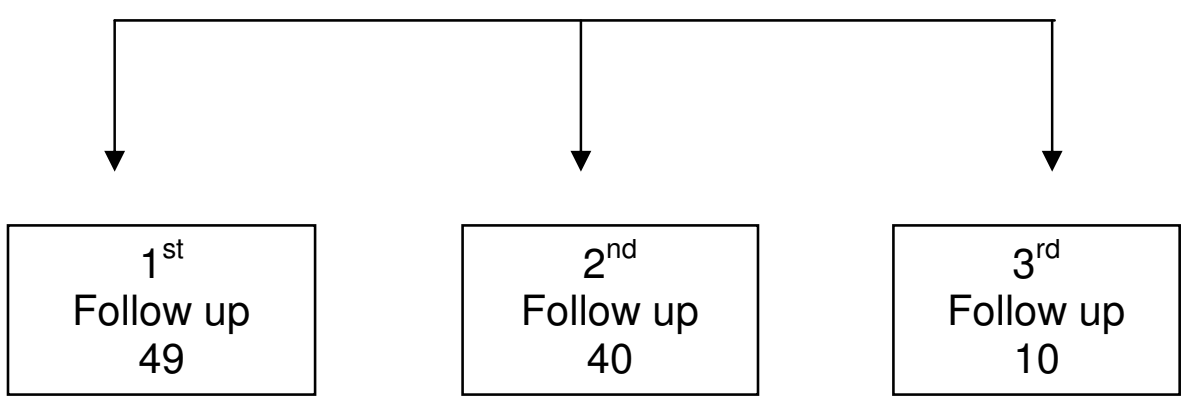

Fig. 1: Study flow chart

\section{Statistics}

Data entry and analysis were performed using Excel, and SPSS software. Simple descriptive statistics were employed. The research complied with research guidelines given by the BPKIHS.

\section{Results}

A total of 258 subjects were examined and 145 were diagnosed to have hypertension in the initial screening. The blood pressure was in the normal range in the younger age groups, with a gradual increase in grades of hypertension with increasing age. Among females, the majority remained normotensive up until the sixth decade, whereas the male participants started to show a higher range of blood pressure by the fifth decade (Table-2). 
Table 2: Age gender and stage of hypertension

\begin{tabular}{|c|c|c|c|c|c|c|c|c|c|c|}
\hline $\begin{array}{c}\text { Age } \\
\text { group } \\
(\text { years) }\end{array}$ & \multicolumn{2}{|c|}{ Normal } & \multicolumn{2}{c|}{$\begin{array}{c}\text { Pre-hyper- } \\
\text { tension }\end{array}$} & \multicolumn{2}{c|}{ Stage 1 } & \multicolumn{2}{c|}{ Stage 2 } & \multicolumn{2}{c|}{ Total } \\
\cline { 2 - 11 } & Male & Female & Male & Female & Male & Female & Male & Female & Male & Female \\
\hline $15-29$ & 15 & 28 & 5 & 14 & 4 & 2 & 2 & 0 & 26 & 44 \\
\hline $30-39$ & 18 & 27 & 11 & 10 & 3 & 6 & 1 & 4 & 33 & 47 \\
\hline $40-49$ & 7 & 10 & 18 & 4 & 8 & 3 & 2 & 2 & 35 & 19 \\
\hline $50-59$ & 3 & 4 & 5 & 7 & 4 & 6 & 8 & 2 & 19 & 19 \\
\hline $60+$ & 0 & 1 & 0 & 1 & 5 & 1 & 4 & 3 & 10 & 6 \\
\hline Total & 43 & 70 & 39 & 36 & 24 & 18 & 17 & 11 & 123 & 135 \\
& $(35 \%)$ & $(51.8 \%)$ & $(32 \%)$ & $(26.7 \%)$ & $(20 \%)$ & $(13.3 \%)$ & $(14 \%)$ & $(8.1 \%)$ & $100 \%$ & $100 \%$ \\
\hline
\end{tabular}

More than $30 \%$ of the screened population were smokers or had smoked regularly in the past and all of them were either regular or occasional drinkers. There was a small but statistically insignificant increase in number of positive family history conditions in cases with stage 1 and 2 hypertension (Tables 3 and 4).

Table 3: Personal history of screened population $(n=258)$

\begin{tabular}{|l|l|l|l|l|l|l|}
\hline \multicolumn{2}{|c|}{ Smoking } & \multicolumn{3}{c|}{ Alcohol } & \multicolumn{2}{c|}{ Physical activity } \\
\hline Smoker & Ex-smoker & No & Regular & Occasional & $\begin{array}{l}<30 \\
\text { minute/day }\end{array}$ & $>30$ minute/day \\
\hline $\begin{array}{l}68 \\
(26.3 \%)\end{array}$ & $19(7.4 \%)$ & $\begin{array}{l}171 \\
(66.3 \%)\end{array}$ & $\begin{array}{l}30 \\
(11.6 \%)\end{array}$ & $228(88.4 \%)$ & $40(15.6 \%)$ & $118(84.4 \%)$ \\
\hline
\end{tabular}

Table 4: Distribution of family history $(n=258)$

\begin{tabular}{|l|l|l|}
\hline & \multicolumn{2}{|c|}{ Family history of diseases } \\
\hline & \multicolumn{1}{|c|}{ Yes } & \multicolumn{1}{c|}{ No } \\
\hline Kidney disease & $\left.9{ }^{*} 3.5 \%\right)$ & $249(96.5 \%)$ \\
\hline Hypertension & $72(27.9 \%)$ & $186(72.1 \%)$ \\
\hline Diabetes & $33(12.8 \%)$ & $225(87.2 \%)$ \\
\hline Heart attack or stroke & $8(3.1 \%)$ & $250(96.9 \%)$ \\
\hline Total & $122(47.3 \%)$ & $136(52.7 \%)$ \\
\hline
\end{tabular}


The waist circumference was less in index showed an increasing trend across normotensive in screened population than in different stages of hypertension (Table 5 and the hypertensive people. The body- mass $6)$.

Table 5: Body Mass index and stage of hypertension

\begin{tabular}{|c|c|c|c|c|}
\hline & $\begin{array}{c}\text { Mean BMI } \\
\text { (male) }\end{array}$ & SD & $\begin{array}{c}\text { Mean BMI } \\
\text { (female) }\end{array}$ & SD \\
\hline Normal & 21.5 & 4.2 & 22.3 & 4.03 \\
\hline $\begin{array}{c}\text { Pre- } \\
\text { hypertension }\end{array}$ & 22.4 & 3.67 & 24.6 & 4.06 \\
\hline Stage 1 & 22.67 & 2.86 & 29.9 & 3.34 \\
\hline Stage 2 & 23.8 & 4 & 28.8 & 3.98 \\
\hline Any & 22.8 & 3.5 & 22.8 & 3.8 \\
\hline
\end{tabular}

Mean BMI between normal and any stage of hypertension, $p==0.07$ in male and $p=0.004$ in females.

Table 6: Waist circumference and waist hip ratio in hypertension

\begin{tabular}{|c|c|c|c|c|c|c|}
\hline & FEMALE & MALE & & \\
\hline & Number & $\begin{array}{c}\text { Mean waist } \\
\text { circumference } \\
\text { With } \\
\text { SD }\end{array}$ & $\begin{array}{c}\text { Mean } \\
\text { Waist hip } \\
\text { Ratio with } \\
\text { SD }\end{array}$ & Number & $\begin{array}{c}\text { Mean waist } \\
\text { circumference } \\
\text { with } \\
\text { SD }\end{array}$ & $\begin{array}{c}\text { Mean } \\
\text { Waist hip } \\
\text { Ratio with } \\
\text { SD }\end{array}$ \\
\hline Normal & 70 & $81(9.69)$ & $0.89(0.08)$ & 43 & $81.5(9.18)$ & $0.9(0.08)$ \\
\hline Pre- & 36 & $86.64(9.6)$ & $0.9(0.05)$ & 39 & $85.4(9.48)$ & $0.95(0.07)$ \\
\hline Stage 1 & 18 & $85.06(8.32)$ & $0.89(0.5)$ & 24 & $88.7(9.46)$ & $0.87(0.07)$ \\
\hline Stage 2 & 11 & $84(17.72)$ & $0.9(0.12)$ & 17 & $92.8(10.72)$ & $0.99(0.064)$ \\
\hline Any & 70 & $85.8(10.9)$ & $\begin{array}{c}0.902 \\
(0.07)\end{array}$ & 80 & $88.0(10.04)$ & $0.97(0.076)$ \\
\hline Hypertension & & & & & & \\
\hline
\end{tabular}


Means of waist circumference between "normal" and "any stage of hypertension", $p=0.001$ in males and $p=0.013$ in females.

First follow-up at 2 weeks was attended by 49 persons. The mean blood pressure had not improved. In fact, the mean systolic blood pressure (SBP) increased by $3.14 \mathrm{~mm} \mathrm{Hg}$ and the mean diastolic blood pressure (DBP) increased by $2.58 \mathrm{~mm} \mathrm{Hg}$. Forty people attended for second follow up after medication (mostly hydrochlorothiazide $12.5 \mathrm{mg}$ or $25 \mathrm{mg}$ ). Compared to baseline, the SBP decreased by $9.15 \mathrm{mmHG}$ and the DBP decreased by $2.93 \mathrm{mmHg}$. Ten people attended for $3^{\text {rd }}$ follow-up. When compared to baseline, the SBP decreased by $27.2 \mathrm{mmHg}$ and the DBP decreased by $15.0 \mathrm{mmHg}$ (Table 7, 8 and 9).

Table 7: BP of those who attended $1^{\text {st }}$ follow up

\begin{tabular}{|c|c|c|c|c|}
\hline & Mean SBP & SD & Mean DBP & SD \\
\hline Initial $(n=49)$ & 144.53 & 22.78 & 92.73 & 12.68 \\
\hline FU1 $(n=49)$ & 147.67 & 22.28 & 95.31 & 13.37 \\
\hline FU2 $(n=40)$ & 133.25 & 16.91 & 88.95 & 9.88 \\
\hline FU3 $(n=10)$ & 119 & 7.38 & 77.8 & 9.02 \\
\hline
\end{tabular}

\section{Discussion}

The present study showed pre-hypertension or hypertension in $56 \%$ individuals, 75 (29\%) had a blood pressure measurement in prehypertensive range, 42 (16.3\%) had hypertension stage 1 and $28(11 \%)$ had hypertension stage 2 .

A similar study in the United States in a family medicine clinic found much higher nearly $80 \%$ of adults with pre-hypertension or hypertension. ${ }^{9}$ No similar studies were found from Nepal in literature search.

Community based studies generally report lower rates than those in clinics or hospitals.
Community based studies have reported that the rates of hypertension to be between 3 and $27 \%$ in Nepal. ${ }^{5}$ A recent community based door-to-door screening for chronic kidney disease, hypertension and diabetes in Dharan, Nepal found $38.6 \%$ of people over 20 years had high blood pressure. Of these, $47 \%$ were not previously diagnosed as hypertensive. ${ }^{11}$

Among those who had an abnormal measurement, approximately half of them were in the hypertensive range, whereas the other half were in pre-hypertensive range. 
The fact that younger age and lower BMl are associated with normal blood pressure is not a surprise. The study showed a clear relationship between stages of hypertension and body mass Index in females $(p=.004)$. Males also showed a trend of increasing blood pressure with $\mathrm{BMI}$, but there was a stronger statistically significant relationship with waist circumference $(p=.0001)$. The link between truncal obesity (as measured by waist circumference), or BMI, and cardiovascular risk is well known ${ }^{7}$ and weight reduction is part of all the recommendations for non-pharmacological management of hypertension. ${ }^{3,4,7}$ Our results confirm the importance of this advice.

Normal blood pressure was found to be more common in the younger age groups, with a gradual increase in grades of hypertension with increasing age. Overall, 113 (44\%) were normotensive and most of these were young. Thirteen of the fifteen people of age 60 years and older had high blood pressure. The data given in the JNC7 report also highlights a strong link between blood pressure and age, in both men and women (JNC7). From this, it is clear that older age groups will have the highest yield from screening. However, previously undiagnosed cases were found in the under 30 age group also, and these people could potentially be those to benefit most from being diagnosed.
For those patients who came for follow-up, an improvement in their BP with treatment was clearly demonstrated over the longer term. At the initial visit, everyone received lifestyle modification advice and only those with graded hypertension were prescribed medications.

Mean blood pressure had not improved at the first follow-up at two weeks but started to show improvement on second follow up. The drop in blood pressure at $3^{\text {rd }}$ follow-up did not achieve statistical significance, because only ten people came to all three follow-up visits. These ten people may also have been the most highly motivated participants who implemented lifestyle changes and therefore achieved the best results. As in any chronic disease, the value of regular follow up and compliance issues must be considered while managing hypertension. A research with longer follow up should be planned to validate this observation

\section{References}

1. North of England Hypertension Guideline Development Group. Essential hypertension: managing adult patients in primary care. Newcastle on Tyne. Centre for Health services and Research Report 2004; 111: P 8-10, 3042, 45-47, 50-60, 70-91.

2. Chobanian AV chairman. Introduction. Seventh report of joint national 
Committee on prevention, detection evaluation and treatment of high blood Pressure. Washington: US Department of Health and Human Services; 2004. www.jnc-7.org accessed 15 th June 2006.

3. Facts about the DASH Eating Plan. NIH Publication No. 03-4082. http://www .nhlbi.nih.gov/health/public/heart/hbp/da sh. Accessed 25 $5^{\text {th }}$ June 2006.

4. Williams B, Poulter NR, Brown MJ, Davis M, Mclnnes GT, Potter JF, et al. Guidelines for management of hypertension: report of the fourth working Party of the British Hypertension Society, 2004-BHS IV. British Hypertension Society Guidelines. Journal of Human Hypertension 2004; 18: 139-185.

5. Chobanian AV, Bakris GL, Black HR, Cushman WC, Green LA, IzzoJr JL, et al. The National High Blood Pressure Education Program Coordinating Committee. The Seventh Report of the Joint National Committee on Prevention, Detection, Evaluation, and Treatment of High Blood Pressure. Hypertension 2003; 42: 1206-1252.

6. Guidelines Committee 2003. Guidelines for the management of arterial hypertension: European Society of Hypertension J Hypertens 2003; 21: 1011-1053.
7. 2005 New Zealand Guidelines Group. New Zealand Cardiovascular Guidelines Handbook. 2005 www.rnzcgp.org Accessed $25^{\text {th }}$ June 2006.

8. Park K. Screening for disease. In: Park's textbook of preventive and social medicine $16^{\text {th }}$ edition. Jabalpur India: BanarsidasBhanot; 2000. P.107-113.

9. Viera AJ. "The New normal blood pressure: what are the implications for family medicine": Family medicine and the healthcare system. J Am Board Fam Med 2007; 20:1

10. Minh HV, Byass P, Chuc NTK, P Byass, S Wall. Gender differences in prevalence and socioeconomic determinants of hypertension: findings from the WHO STEPs survey in a rural community of Vietnam. Journal of Human Hypertension advance online publication 29 September 2005.

11. Sharma SK, Karki P, Shrestha NR, Thapa L, Perico N, Perna A, et al. First community based screening for chronic kidney diseases hypertension and diabetes in Dharan, Nepal 2006.

12. The Seventh Report of the Joint National Committee on Prevention, Detection, Evaluation, and Treatment of High Blood Pressure; National Heart, Lung, and Blood Institute Information Center. 
www.nhlbi.nih.gov/guidelines/hypertensi on/jnc7full.http Accessed on $25^{\text {th }}$ June 2006

13. The Seventh Report of the Joint National Committee on Prevention, Detection, Evaluation, and Treatment of
High Blood Pressure, JAMA 2003; 289:2560-2572. Accessed from www.nhlbi.nih.gov/guidelines/hypertensi on/jnc7full.htm Accessed on $25^{\text {th }}$ June 2006 